\title{
Principled Eclecticism: Approach and Application in Teaching Writing to ESL/EFL Students
}

\author{
Sultan H. Alharbi ${ }^{1}$ \\ ${ }^{1}$ Department of English Language \& Translation, King Saud University, Riyadh, Saudi Arabia \\ Correspondence: Sultan H. Alharbi, Department of English Language \& Translation, King Saud University, \\ Riyadh, Saudi Arabia. E-mail: suhalharbi@ksu.edu.sa
}

Received: December 1, 2016

Accepted: January 3, 2017 Online Published: January 5, 2017

doi: 10.5539/elt.v10n2p33

URL: http://dx.doi.org/10.5539/elt.v10n2p33

\begin{abstract}
The principal purpose of this paper is to critically examine and evaluate the efficacy of the principled eclectic approach to teaching English as second/foreign language (ESL/EFL) writing to undergraduate students. The paper illustrates that this new method adapts mainstream writing pedagogies to individual needs of learners of ESL/EFL in order to address students' difficulties arising from their contact with an unfamiliar language. Such a claim is based on the researcher's review of relevant research, the analysis and evaluation of scholarly studies on the subject by leading academics and authorities in the area, and the researcher's practical experiences as a writing teacher in the Department of English Language and Translation (DELT), College of Languages and Translation (COLT), King Saud University (KSU). It has been generally observed that the common, time-honored, language-based, process-based, and genre-based approaches to teaching writing tend to troubleshoot only certain specific problems related to the teaching of ESL/EFL writing. This paper highlights the importance of student-centered approaches to teaching in order to achieve the goal of coherent, pluralistic language teaching. To achieve this, the discussion recommends classifying, selecting, and sequencing the activities related to teaching writing. Indeed, this is what eclecticism means. The term principled signifies coherence that consistently focuses upon the same formal or functional units and sequencing them at the end to help learners interact and participate in writing activities that need contextualized attention. The paper concludes that the gap between eclecticism and principled eclecticism in teaching English writing must be bridged to improve ESL/EFL learners' writing skills.
\end{abstract}

Keywords: ESL/EFL, writing skill, teaching methodology, principled eclectic approach, DELT

\section{Introduction}

The acquisition of English writing skills has gained tremendous importance not only as an academic skill, but with the expansion of businesses worldwide and the economic and cultural globalization, it has also become an important skill that translates into any career field. By virtue of being the most important language link, nearly all professions require some form of writing on the job. Whether it is writing medical reports, financial reports, instructional sheets, and user manuals written by software engineers or emails and other forms of written communication in all kinds of businesses, the role of writing as a multi-target English as a second/foreign language (ESL/EFL) tool is significant and expanding. Writing also equips us with the communication and thinking skills we need to participate effectively in any activity. Given the paramount importance of English language, there is an overwhelming surge in learners of ESL/EFL writing seeking to acquire the necessary skills to achieve success in their area of occupation. Teaching writing skills to ESL/EFL learners has its own intrinsic problems, and various teaching methodologies and different approaches have been therefore introduced in language classrooms to teach writing to ESL/EFL learners. All these approaches have doubtlessly helped ESL/EFL acquire the requisite writing skills in English and display a certain command of English language, but the teaching of writing and its acquisition are not linear processes; they require a multi-layered, recursive procedure. Considerable time must be made available for review. Teachers have to emphasize expanding and improving the learners' critical faculties so they can assess and mull over their writing composition as well as evaluate their strengths and weaknesses in relationship to their works (Foster, 1992). In the same spirit, it is also imperative that writing instructors draw on learners' cultural, social, and geographical backgrounds and keep them in proper perspective while teaching writing skills in language classrooms. 
It is for this purpose that a realistic approach to language learning has to be introduced. The principled eclectic approach, in this respect, has appeared as the most effective way of learning and teaching writing to ESL/EFL learners. This concept shall be substantiated and demonstrated in the Discussion section, with attestations from experts in the field. The principled eclectic approach starts with the writing instructor's valid awareness of the student's needs with respect his or her environment. The eclectic approach stresses using a variety of methodologies and approaches, choosing techniques from each method that the instructor deems effective and applying them according to the learning context and objectives. Larsen-Freeman (2000) devised the term principled eclecticism to demonstrate a coherent and pluralistic approach to language learning. The term principled, when applied to the eclectic approach, signifies that the use of a variety of language learning activities must be guided by giving appropriate importance to the different components of language learning rather than separating them into chunks of grammar and vocabulary. Language learners come with diverse experience goals; therefore, a writing course must be designed in response to their goals and objectives. This is what principled eclecticism stresses. Only after understanding the future needs of learners can instructors design a practical and functional writing course incorporating various instructional skills. Accredited scholars and researchers on writing pedagogy have asserted that no single writing methodology can be sufficiently helpful in teaching writing to learners with diverse linguistic and cognitive abilities (e.g., Kumaravadivelu, 2006; Nunan, 1991). They can fall short of producing the desired learning outcomes in learners with different social, cultural, and rhetorical predispositions. Thus, it is necessary for ESL/EFL writing teachers to undertake a well-rounded approach to meet the diversified needs of their learners. This is possible only through a principled eclectic approach, which combines the text, the context, and the learners (Mellow, 2002).

The current paper analytically examines the scope and utility of the principled eclectic approach to teaching of writing as a second language. It investigates and tests its efficacy in terms of the learning outcomes with regard to the learners. The discussions and conclusions herein are advanced and supported by various research findings by authorities in the field and by empirical evidence and an extensive and critical discussion on the research topic. The outcomes and the inferences drawn in this paper are based on the assumptions that the ESL/EFL teacher exploits various teaching resources that stimulate learners to compose relevant writing lessons. It is impossible to use only one method when teaching writing to students with varied backgrounds and different goals. The principled eclectic method has been regarded as the most effective way of teaching language, and it makes learning interesting and innovative due to the unique nature of the learning process (Kumar, 2013). The Discussion section of this paper shows how this approach can be used in teaching writing and delineates this phenomenon more explicitly and elaborately. This work can serve as a guideline to ESL/EFL teachers of writing and encourage them to use the methodology of principled eclecticism to motivate students to write professionally and independently.

\section{Literature Review}

With the tremendous upswing and growing interest in learning about ESL/EFL writing, researchers and ESL/EFL teachers have been busy developing an approach and employing a methodology that cater to the needs of contemporary ESL/EFL learners. Such a need is becoming increasingly urgent as more and more learners are joining ESL/EFL writing classes due to the growing demands of English writing to participate in the globalized world of trade and commerce (Leki, 2002). Moreover, traditional methodology does not present the language as a means of communication. The teaching of writing has been based on the idea of giving information to the learners about the grammar and the structures of the language through various exercises in the course books. Students were expected to learn this information, with an emphasis on intellectual rigor. Meanwhile, pluralism associated with the idea of eclecticism carries in itself the freedom to select teaching methodologies that cohere with specific learning needs, thereby emboldening learners to communicate through their writing abilities.

According to Kumar (2013), teaching language using the eclectic method involves a rich combination of multiple activities, including participatory, communicative, and situational approaches. He observed that an ESL/EFL writing classroom includes heterogeneous students with varied levels of language intelligence, and the teacher has to use multiple methodologies of language teaching, giving particular attention to the learners' cognition and linguistic objectives. Kumar defines this as a holistic eclectic language teaching approach. Hyland (2007), on the other hand, asserts that, in order to teach ESL/EFL writing to learners from varied cultural and geographical backgrounds, it is pertinent to use a variety-based methodology, which he calls "genre-based pedagogies." He argued that this will offer a valuable resource for helping instructors and learners produce effective and relevant texts. In Hyland's (2007) view, the genre-based pedagogy provides educators a more effective tool in preparing ESL/EFL learners in different capacities, creating variety in their teaching, after carefully planning, sequencing, and assessing the learning objectives and outcomes. 
Recent decades have witnessed a change from traditional writing approaches to an integrated, pluralized, and eclectic approach to be implemented in writing classroom practices. Eclecticism is a pedagogical strategy that moves away from teachers following one specific methodology in order to assimilate different existing methodologies and approaches, according to the learners' needs (Lazarus \& Beutler, 1993). In this strategy, the teacher is left free to choose the methodologies useful for learners in a given circumstance. In a typical writing classroom, the instruction is based on a combination of various approaches, such as the communicative approach, the lexical approach, and the structural-situational approach. This helps the teacher establish a clear, need-based context, with flexible writing strategies to suit learners' learning goals (Yonglin, 1995). Language teaching experts and researchers invariably uphold the effectiveness of the eclectic approach in teaching ESL/EFL writing because they believe that it liberates them from the inflexible, traditional, teacher-oriented teaching methods. Lecture-based, blackboard-supplemented, teacher-centered writing lessons give no alternative to either the teachers or the learners. With the traditional approach, writing became a merely classroom activity. The eclectic approach has the potential of keeping the language teacher open to alternatives. Here, the teacher has to embrace and actively seek out new techniques, trying them out in their professional practice all the time in terms of their underlying rationale (Weideman, 2001).

Howard (2001) argued that the eclectic approach in teaching writing composition holds a particular fascination for learners. It enhances small-group discussion and peer response, in which students individually draft an assigned paper and then classmates respond, making suggestions for improvement. The basic thrust of the eclectic approach, which Howard termed as collaborative pedagogy, is to enhance students' experience of writing, with instructors acting as motivators and evaluators. But many language teaching experts believe that eclecticism does not imply the use of unrestrained liberty in mixing arbitrarily chosen methodologies. They believe that no single method of teaching writing works well for all students. Thus, they recommend that composition teachers need to have a big bag of pedagogical tricks. These tricks or improvisations must adapt to the variety of learning styles that the learners bring with them into the classroom (Xiao-yun et al., 2007). Xiao-yun et al. (2007) added "principled" to the term eclecticism in order to put certain conditions on the choice and implementation of the eclectic approach to teaching writing.

According to Mellow (2002), principled eclecticism is the most appropriate, logical, and pluralistic language teaching approach that stresses an assorted recipe of learning activities depending on learners' needs. It reinforces the employment of a wide range of language learning activities with diverse features to help the teachers and learners engage in holistic composition learning. Rodgers (2001, p. 4) envisaged that principled eclecticism, which he termed "disciplined eclecticism," is expected to shape and change the teaching of second language in the future. He believed that, because traditional ESL/EFL writing methodologies are concerned only with the skills dealing with language mechanics (e.g., language, text, and composition), adherence to the traditional approach would lead to a slanted aspect of language writing, which is a comprehensive and complex skill involving reading and cognitive skills. Thus, it becomes inevitable to use a variety of suitable approaches to provide scope and range to the learning of writing skill, which it so pragmatically needs. Responding to the demand for a pluralistic and principled eclectic approach, Larsen-Freeman (2000) used the term "informed eclecticism" or "enlightened eclecticism" when discussing L2 writing pedagogy. He underscored the growing dissatisfaction among instructors of ESL/EFL writing in failing to address the learning needs of non-native learners.

Nunan (1991, p. 228) stated that "it has been realized that there never was and probably never will be a method for all." In his discussion on diagnosis, treatment, and assessment with respect to ESL/EFL pedagogy, Brown (2002, p. 13) suggested the use of principled eclecticism, where teachers select the teaching methodology that synchs well with their own dynamic contexts. In this approach, teachers select the syllabus and devise the course designs and objectives with a view to the learners' specific needs in their learning contexts. Principled eclecticism, therefore, throws a challenge to language teachers to remind them that any decision they make must be based on a complete awareness of the purpose and context of language learning as well the needs of language learners. Teachers who make use of the eclectic method must be conversant with all teaching methodologies, knowing full well how language is learned, and how and what teaching is all about (Brown, 2002). In his discussion on principled eclecticism, Kumaravadivelu (2001) defined the methodology, which he also addressed as a post-method pedagogy, as a focused context-sensitive language learning approach, congruent with the understanding of local linguistic, socio-cultural, and political exigencies to enable teachers to construct their own theory of practice. In a review of TESOL methods, Kumaravadivelu (2006, p. 60) pointed that the major change that has taken place in teaching English to ESL/EFL learners relates to the shift from method-based pedagogy to post-method pedagogy, in which written and oral exercises are utilized to improve learners' language accuracy, 
fluency, and communicative ability.

\section{Discussion}

ESL/EFL writing teachers have long used the mainstream approaches to teaching writing as a mainstay of their language teaching methodology. But many researchers feel that the traditional teaching methodologies do not address the problems that a vast variety of language learners experience in their ESL/EFL writing classes. Reflecting on the need to bring about a shift in ESL/EFL writing pedagogy, Scarcella and Oxford (1992) suggested in their book The Tapestry of Language Learning: The Individual in the Communicative Classroom that pedagogical choices must be governed by students' multicultural needs. They argued that, because individual students bring distinct learning styles to the classroom, individual and cultural differences in writing significantly affect classroom pedagogy. Based on this observation, ESL/EFL teachers have to improvise their teaching pedagogy in tune with learners' needs and not follow the beaten track that has now become defunct with a transformation in the language learning scenario.

In his research experiments, Kumaravadivelu (2006) demonstrated that the ESL/EFL writing classrooms consist of such a large variety of language learners, with such divergent learning needs and aptitudes, that the teacher has to employ a fit-for-all teaching technique. In such classrooms, instructions must underscore the need to use a variety of language teaching approaches in order to connect with all the students and adhere to the "local needs, creating local pedagogies to address students' difficulties, and critically examining and evaluating extant mainstream writing practices" (Kumaravadivelu, 2006, p. 60). Language teachers must use the eclectic approach to teaching writing in a principled way, adapting it to the traditional writing methodology, so that learning becomes effective, productive, and practical-what language teaching experts call the principled eclectic approach.

The teaching of ESL/EFL writing can only be effective and functional if particular care is given to understand the social, creative, and cognitive aspects of language learning, which would necessarily involve not one particular approach, but a variety of carefully selected teaching approaches. Only then can the teaching of writing achieve its underlying goal. The first step in moving toward a pluralistic writing instruction methodology is to outline the course objectives. This goal setting must depend on what learners want to learn and what their expectations are, followed by the teacher's choice of methodology based on pragmatic and instrumental grounds befitting the learners' career aspirations. For example, students of literature and linguistics need to be taught academic essay writing, so that they are competent in writing essays and compositions that pertain to a general and wide area of topics requiring creativity and independence. Writing in English is essentially an evolving process that takes into consideration the linguistic, cognitive, social, and cultural aspects, which demands a multidimensional approach (Kucer \& Silva, 2006) to achieve effective written communication in order to meet the expectations of a certain discourse community (Swales, 1990, 2004). Writers employ certain cognitive strategies in the process of writing, like planning the essay and reviewing and proofreading, in order to construct meaning. This cannot be successfully taught without including the traditional approach, which is largely based on lexis and grammar. This approach has to include a broader spectrum of reading and writing activities, such as writing the topic sentence or thesis statement and analyzing the pragmatic functions of language, where the learners have to be trained to read like perceptive writers and write like a thoughtful reader.

Therefore, it is not inappropriate to suggest that, before learners embark on their first draft, teachers of ESL/EFL writing should apply mainstream teaching methodologies that include observing the grammatical rules, patterns, and structures while making sentences and collecting a repertoire of vocabulary. In the second stage, when learners actually start writing their compositions, teachers devise and improvise a practical and systematic instruction based on students' needs and the exigencies of the writing goals. This is what principled eclecticism signifies. This methodology strives to teach students to integrate each writing methodology that they have learned with their desired goals and the objectives with which they are learning writing. This kind of pluralistic methodology also includes other features of language, like reading comprehension, idea generation, and rhetorical analysis, which assists ESL/EFL learners of writing in attaining the mandatory language competence and subject expertise that is indispensable for writing an original, practical composition (Kroll, 1993).

The eclectic approach can be employed by utilizing diverse language activities, like combining sentences, separating sentences, identifying pronouns and their antecedents, and teaching words (and their synonyms) and prepositional phrases, focusing on specific features of the language relevant to learners' contextual needs. As these language activities are divergent, they compel the teachers to cohere them with the objectives of the group of ESL/EFL learners in writing composition. Zamel (1982) concluded that learners have to be trained to consider how to connect their language with the ideas communicated to them. This kind of linking device requires a 
teaching approach that stresses the creation of a linguistic structure before learners begin composing their first draft. After a series of lessons in grammar and sentence structures and drafts of their own papers, learners are then asked to examine sample essays compared to their own essays. The eclectic approach encourages inputs from peers and teachers in planning, drafting, and revising a composition. It is not merely teacher-centered approach, but includes the participation of other learners. In this approach, the choice of topic is left to the learners rather than being dictated by teachers. It is a natural teaching method whereby students write about whatever interests them. To make the eclectic approach more effective and integrative, the writing project seeks to engage students with each other in specifiable writing tasks.

The ESL/EFL writing instructor has to understand that a learner's writing style reflects his/her personality type. Some learners like to work in a group while others do not. No single writing methodology can be successful in such a varied class of ESL/EFL learners. The principled eclectic method, therefore, involves a recipe for different methodologies appropriate in a given circumstance in order to make the learners active, hands-on participants in each aspect of a structured learning process. According to Myers and Myers (2010), one's personality type significantly influences life decisions, such as which career to pursue. Some students are intuitive and emotional whereas others are rational, decisive, and practical. Still others are more extraverted and practical than introspective and creative. Hence, with reference to the personality types, each composition class has to have a diversity of approaches in tandem with the writing styles of learners and also in harmony with the expectations of the learners. This can be done when the teacher focuses on a well-informed eclecticism, making the teaching more learner-centered. When using principled eclectic methodology, the teacher introduces learners to a variety of exercises to improve their facility in writing and keep them focused on their learning goals and needs. The language teacher needs to be proactive in correcting students' errors, thereby developing learners' linguistic capabilities. In eclecticism, learners are facilitated to tailor not only the lexis and grammar construction, but also the various functions of language and its idioms. It cannot be achieved with only one language pedagogy, which is why skilled ESL/EFL instructors stick to principled eclecticism, where students are also inspired to be self-sufficient in their learning.

Writing is basically and essentially an academic skill. At its primary and core level, it starts with the building up of correct sentences with coherent syntactic and semantic structures. At succeeding levels, it develops into a craft and a cognitive process, using a rule or procedure that can be applied repeatedly. Thus, the role of the teacher in an ESL/EFL writing class is to teach across-the-board and guide students through a mixed baggage of methodologies concentrating on the learners' needs, because effective writing requires competence in a wide variety of creative, social, and cognitive processes. On the part of the instructor, principled eclecticism, with regard to ESL/EFL writing, entails a comprehensive knowledge of all learning theories, ranging from the grammar-translation to the audio-lingual technique to the more communicative methods that are frequently exploited today, in terms of the purpose and context of language learning and the needs of the language learners. It should not merely be a simple arrangement of different teaching options. Instead, it should be a systematic instructional approach based on the specific dynamic context of the ESL/EFL learners.

\section{Limitations}

Principled eclectic methodology has its own share of shortcomings. Some ESL/EFL researchers on writing cast doubt on the efficacy of the collaborative writing approach. They argue that some learners tend to be reticent about sharing their compositions with their classmates. They distrust their peers and prefer the authority of a teacher's feedback. In certain cases, learners shower fulsome praise on each other's works (Spear, 1988). Despite this, the overall belief is that peer conferencing and collaborative learning as an aspect of principled eclectic methodology work well with learners by helping them write better and focus on their writing goals. Another pitfall of this method is that, as it entails maximum teacher-learner interaction, it is possible that the teacher might give learners the impression that he/she is exerting too much control over the writer's voice and usurping the composition. In this case, the approach can be counterproductive. The instructor has to deal very carefully with the learners, without imposing his/her knowledge and position, and offer advice only where the learners need it. This would give the message to the learners that their instructor is giving them space and will help them develop. The eclectic method has to be based on outcomes and centered on the learners' needs.

Although principled eclecticism relies, to a great extent, on learners collaborating with each other in revising and proofreading written drafts and interacting with the teacher whenever there is confusion, some learners may be reluctant to work with their peers or to provide honest feedback. In such cases, the teacher has to become proactive by giving learners specific guidelines for interacting with their peers at each stage of their writing process. Teacher monitoring and observation are critical aspects of principled eclecticism, specifically in teaching ESL/EFL writing skills. 


\section{Conclusion and Suggestions}

There can be no single method of teaching writing. It is quite obvious that writing skill requires creative competence. Writing also needs the activation of critical skills requiring extensive cognitive activity and planning. Moreover, a written text follows certain required language structures, along with the use of adequate phrases or vocabulary congruent with the learning perspectives, objectives, and outcomes. A written composition also needs a lot of redrafting, proofreading, and editing. Furthermore, particular care has to be given to the fact that different language learners have different learning styles. All these aspects and ground realities highlight the fact that a writing instruction teaching writing classroom has to be eclectic, holistic, and need-based. The constraint here is that it is not easy to find instructors who are comprehensively competent in teaching ESL/EFL writing in a situation that is ever-changing. Therefore, the need, now more than any other time, is to train teachers of ESL/EFL writing so that they are capable of teaching with specific and concrete instructions and encourage learners to help them learn to write well according to their local exigencies.

In an ESL/EFL writing classroom, the basic thrust of the principled eclectic approach is to reach all students despite the diversity in learning styles and intelligences inherent in most composition classes. It is a learner-centered classroom activities approach, where teachers engage students in group work and individually on writing tasks. Thus, the ESL/EFL writing teacher needs to develop an excellent understanding of the problems directly related to learners' needs in order to solve learners' multiple writing problems successfully. This requires the choice of an approach that addresses the issue of learners' needs and styles.

The current paper has underscored the need of employing, encouraging, and reassuring writing tasks required in learners' real lives. As asserted herein, the aspects of language writing and form must conform to learners' learning needs to generate effective writing. The layout of the composition, its paragraphing, the linking of ideas, the appropriate word choice, and the economy of phrasing should cohere with the purpose, content, and writing situation. The paper contends that principled eclecticism can be successful only when the teacher is competent in the knowledge of all the mainstream writing pedagogies and has a complete grasp of the learners and their needs. In addition, the teacher must know well enough how to improvise the methodologies, keeping a keen eye on the learning goals and outcomes in an ESL/EFL writing classroom, so that principled eclecticism can be implemented holistically and successfully.

\section{References}

Brown, H. D. (2002). English language teaching in the "post-method" era: Toward better diagnosis, treatment, and assessment. In J. C. Richards, \& W. A. Renandya (Eds.), Methodology in language teaching: An anthology of current practice (pp. 9-18). New York: Cambridge University Press. https://doi.org/10.1017/CBO9780511667190.003

Foster, D. (1992). A primer for writing teachers: Theories, theorists, issues, and problems (2nd Ed.). Portsmouth, $\mathrm{NH}$ : Boynton/Cook.

Howard, R. M. (2001). Collaborative pedagogy. In G. Tate, A. Rupiper, \& K. Schick (Eds.), A guide to composition pedagogy (pp. 54-70). New York: Oxford University Press.

Hyland, K. (2007). Genre pedagogy: Language, literacy, and L2 writing instruction. Journal of Second Language Writing, 16, 148-164. https://doi.org/10.1016/j.jslw.2007.07.005

Kroll, B. (1993). Teaching writing IS teaching reading: Training the new teacher of ESL composition. In J. Carson, \& I. Leki (Eds.), Reading in the composition classroom: Second language perspectives (pp. 61-82). Boston, MA: Heinle \& Heinle Publishers.

Kucer, S., \& Silva, C. (2006). Teaching the dimensions of literacy. Mahwah, NJ: Lawrence Erlbaum Associates, Publishers.

Kumar, C. P. (2013). The eclectic method-theory and its application to the learning of English. International Journal of Scientific and Research Publications, 3, 1-4. https://doi.org/10.15373/22778179/July2014/173

Kumaravadivelu, B. (2001). Toward a post-method pedagogy. TESOL Quarterly, 35, 537-560. https://doi.org/10.2307/3588427

Kumaravadivelu, B. (2006). TESOL methods: Changing tracks, challenging trends. TESOL Quarterly, 40, 59-81. https://doi.org/10.2307/40264511

Larsen-Freeman, D. (2000). Techniques and principles in language teaching (Teaching Techniques in English as a Second Langauge) (2nd Ed.). Oxford, UK: Oxford university press. 
Lazarus, A., \& Beutler, L. (1993). On technical eclecticism. Journal of Counseling \& Development, 71, 381-385. https://doi.org/10.1002/j.1556-6676.1993.tb02652.x

Leki, I. (2002). Teaching L2 writing at the turn of the century and new perspectives. In R. Manchon (Ed.), Writing in the L2 classroom: Issues in research and pedagogy, Special Issue of International Journal of English Studies (pp. 197-209). Murcia, Spain: University of Murcia.

Mellow, J. D. (2002). Towards principled eclecticism in language teaching: The two-dimensional model and the centering principle. T-EJ, 5, 1-A. Retrieved September 11, 2016, from http://tesl-ej.org/ej20/a1.html

Myers, I., \& Myers, P. (2010). Gifts differing: Understanding personality type. Mountain View, California: Davies-Black Publishing.

Nunan, D. (1991). Language teaching methodology. Sydney: Prentice-Hall.

Rodgers, T. (2001). Language teaching methodology (ERIC Issue Paper). Washington, DC: ERIC Clearinghouse on Languages and Linguistics.

Scarcella, R. C., \& Oxford, R. L. (1992). The tapestry of language learning: The individual in the communicative classroom. Boston, MA: Heinle \& Heinle Publishers.

Spear, K. (1988). Sharing writing: Peer response groups in English classes. Portsmouth, N.H: Boynton/Cook Publishers.

Swales, J. M. (1990). Genre analysis: English in academic and research settings. Cambridge, UK: Cambridge University Press.

Swales, J. M. (2004). Research genres: Explorations and applications. Cambridge, UK: Cambridge University Press. https://doi.org/10.1017/CBO9781139524827

Weideman, A. (2001). The old and the new: Reconsidering eclecticism in language teaching. Per linguam, 17, $1-13$.

Xiao-yun, Y., Zhi-yang, Z., \& Peixing, D. (2007). Principled eclecticism in college English teaching in China. Asian EFL Journal, 17, 1-38.

Yonglin, Y. (1995). Trends in the teaching of writing. Language Learning Journal, 12, 71-74. https://doi.org/10.1080/09571739585200491

Zamel, V. (1982). Writing: The process of discovering meaning. TESOL Quarterly, 16, 195-209. https://doi.org/10.2307/3586792

\section{Copyrights}

Copyright for this article is retained by the author(s), with first publication rights granted to the journal.

This is an open-access article distributed under the terms and conditions of the Creative Commons Attribution license (http://creativecommons.org/licenses/by/4.0/). 